\title{
Between Individualism and Community
}

\section{On Media Consumption, Political Interest and the Public}

\author{
Johannes Andersen \& Niels NørgaArd Kristensen
}

\begin{abstract}
Media consumption in Denmark as well as other western democracies seems to be in transition in several ways. Fewer people keep up with politics and societal developments. Still, on the other hand, people show considerable political confidence and belief in personal political skills as well as in possibilities for making a "difference". Often this phenomenon is given a theoretical foundation in the notion of "reflexive individualization".

This chapter draws the contours of an emerging role of political citizenship and identity: The individualized citizen. Embodied here is a character which is highly engaged and interested in politics, but at the same time does not follow along with current events in the media.

The media continues to play an important role as a central tie between laymen and political authorities but its status and functioning is changing and its decisive role in democracy might be in decay.

The individualized citizen represents a subjectivization and individualization of the political. The awareness and the scope and horizon of political orientations and engagement is increasingly turned on towards personal interests - possibly resulting in an erosion of the public spirit or the common good. The final section of the chapter also discusses possible consequences of a gradual cut between political elites and ordinary citizens.
\end{abstract}

Key Words: media consumption, political interest, the public sphere, reflexive individualization, political identity, political communication

\section{Introduction}

Media consumption in Denmark and other traditional democracies is changing dramatically. Fewer and fewer people take the time to read their newspaper thoroughly, and the number of daily readers is also falling slightly (the spread of the distribution of free newspapers has meant that newspaper readership has not fallen more dramatically than is already the case). The radio is increasingly used as entertainment and background music instead of as a key to orienting oneself about central political events. There are still many television viewers, of course, but there are no longer quite as many who are primarily interested in using the television to orient themselves and keep up with politics and the general developments in society. As with the radio, the television is increas- 
ingly used for entertainment, and most people have few qualms about skipping a news transmission or two. Finally, conceptualizations are developing as regards the diverse stream of political information and debates that have become accessible as a result of the spread of the Internet.

At the same time, reflexive individualization has made an increasing impact (Giddens 1996), which has, among other things, contributed to the dramatic weakening of, e.g., class identity, the right-left orientation in political questions and close connections between voters and parties. At the same time, the political self-confidence of modern citizens has been fortified. They know more and more about what they want and what they do not, as well as how to get what they want. They are not afraid of raising their demands to the authorities and politicians, and they are constantly considering how they can position themselves optimally in the political universe (Goul Andersen et al. 2000), including the media sources they can use and how they can best approach an issue if they wish to influence the public debate. In other words, the media continue to play a role as a central tie between the population and political authorities. This is based on the logic that when something is going on in the public, i.e. something that has attracted the attention of the central media, the authorities must address it (Togeby et al. 2003, p. 215).

In short, significant tendencies can be observed in terms of a change in one cornerstone of the political public, i.e. the media. On the one hand, their 'natural' status as the forum and channel for disseminating political debate and information is weakened, while on the other, they are increasingly employed in strategic communication with the people they wish to impact; for example, in the case of a young couple that uses the media to expose a real estate company and problematic legislation after having been cheated out of an apartment (Politiken, 19.07.2005). At the same time, political engagement is becoming increasingly individualized, which is among the factors contributing to a weakening of social capital (Putnam 2000, p. 216ff).

The result of these two tendencies is not necessarily a weakening of the public's political interest and political participation. Actually, further to reflexive individualization, one can easily imagine widespread political participation and interest. Nor does it necessarily mean that the media are losing their significance, but rather their status and function. However, the central question is whether this combination of the shift in the placement of the media in the public sphere and the increasing individualization of the political sphere has a decisive impact on the political culture, e.g., whether it affects the character of the public's political interest. This will be examined more closely in the following sections.

\section{Political Engagement, the Media and the Public}

Political interest is fundamentally structured around two factors: on the one hand, knowledge about political conditions and, on the other, normative engagement in the form of basic opinions about what is good and bad in society. The more one knows, the more engaged one becomes, as one sees the perspectives and consequences in any given situation. Moreover, the more one becomes engaged in relation to a given perspective or phenomenon, the more political interest one displays.

The balance between these two elements cannot be determined beforehand, but one cannot approach political questions on the basis of knowledge alone. A normative element is necessary if one is to point out a perspective for political engagement. Nor can 
one focus on opinions alone. A minimum of knowledge about what is going on is necessary in order to relate normatively to the developments in society. The two factors are therefore very closely interrelated. Naturally, the ideal is a combination of comprehensive knowledge and a pronounced normative political interest.

Nor is it simple to determine what is impacting what according to a development perspective. Knowledge affects personal involvement and one's interests, while at the same time personal involvement often means that the individual citizen acquires experience with political life and the opportunities one can pursue in order to make a difference, which again often leads to an increased need for information and knowledge (Buckingham 2000). In any case, there is talk of contexts that are closely associated with the political public, political socialization and political learning, and thereby also closely connected in practice with media consumption.

In order to further illustrate the questions referred to in the above, attention in the following is devoted to the connection between political interest and media consumption in Denmark. This connection can be illustrated in a figure combining interest and media consumption. The result is a typology consisting of four different citizen types, as indicated in Figure 1. Further to this point, one can articulate a number of assumptions regarding central development tendencies and thereby a number of theses that will be pursued more closely below.

Figure 1. Political Interest and Media Consumption

\begin{tabular}{|l|l|l|l|}
\hline \multicolumn{2}{|l|}{} & \multicolumn{2}{|c|}{ Political interest } \\
\hline $\begin{array}{l}\text { Use of the } \\
\text { media for } \\
\text { political } \\
\text { orientation }\end{array}$ & Daily & $\begin{array}{l}\text { The active citizen is involved } \\
\text { and well-oriented. Here, } \\
\text { great political interest is } \\
\text { combined with extensive } \\
\text { media usage and presumably } \\
\text { also with extensive political } \\
\text { participation. }\end{array}$ & $\begin{array}{l}\text { The faithful citizen feels that } \\
\text { one is obligated to keep up } \\
\text { with political events. Or the } \\
\text { conservative citizen, who } \\
\text { must assure herself that the } \\
\text { world is still there, and } \\
\text { otherwise simply continues } \\
\text { with her daily routine. Here, } \\
\text { extensive - perhaps ritual or } \\
\text { habitual - media consump- } \\
\text { tion is combined with a } \\
\text { limited political interest. }\end{array}$ \\
\hline $\begin{array}{l}\text { Occasionally or } \\
\text { rarely }\end{array}$ & $\begin{array}{l}\text { The individualistic citizen is } \\
\text { involved without keeping up } \\
\text { with political events through } \\
\text { the media. A citizen who } \\
\text { possibly first and foremost } \\
\text { believes in her own } \\
\text { subjective interests. Here, } \\
\text { widespread political interest } \\
\text { is combined with limited } \\
\text { media consumption. }\end{array}$ & $\begin{array}{l}\text { The indifferent citizen, who is } \\
\text { not interested in politics or } \\
\text { community. Here we observe } \\
\text { a lack of political interest } \\
\text { combined with limited media } \\
\text { consumption in relation to } \\
\text { politics. Conversely, one can } \\
\text { easily imagine extensive } \\
\text { media usage for } \\
\text { entertainment purposes. }\end{array}$ \\
\hline
\end{tabular}

The two classical types are the active and indifferent citizens, which traditionally represent polar opposites. Numerous studies have been carried out for the purpose of identifying these types more closely (preferably with grading between the two poles) 
(Andersen et al. 1993, p. 209). The point made in these studies has often been that the role as citizen is an invitation extended to the citizen to become an active citizen; just as it has also been broadly perceived that the greater the citizen's experience with political participation, the greater the likelihood that he/she will be active. This is entirely in keeping with the traditional perceptions of the significance of political learning (Nørgaard Kristensen 1998). At the same time, it has also long been held by many that those assuming the active citizen role simultaneously develop a political perspective that emphasizes the democratic community, i.e. both the democratic norms and procedures, on the one hand, and a political perspective that entails fighting for the good life for the benefit of the community, on the other. This is a basic assumption in a long number of theories about political engagement (Bang et al. (ed.) 2000).

The passive citizen is regarded as the precondition for the active citizen, and the active citizen is, in turn, a precondition for the functioning of a democratic political system. If nobody will assume the role of, e.g., candidate for a popularly elected assembly, active party member and debating citizen, the democratic system cannot function. On the other hand, it is not necessary for everyone to be active, meaning that both positions are legitimate.

The position as faithful citizen has also traditionally played a certain role, but theoretically it has not been regarded as a central figure. Citizenship as an obligation has always represented a logical possibility, but as long as the engagement has solely been motivated by a sense of obligation and not an actual interest in becoming involved in the political sphere, it has been difficult to respect this position. This citizen type is all too reminiscent of passive and faithful (party) soldiers who do what they are told.

The latter position or type is identified as the individualistic citizen, which embodies something of a contradiction: a citizen who is engaged and interested in politics, but does not follow along with current events in the media. This poses a theoretical and practical challenge, and there has not been significant focus on this variant in the past. As reflexive individualization continues to spread, however, there is reason to take this combination seriously, as there can well be talk of a citizen type that is on the rise, not least among the youngest generations. Furthermore, there is talk of a citizen who first and foremost emphasizes subjective engagement and the interest in making a difference to advance his/her own interests instead of pursuing knowledge, nuances and optimal solutions for the common good.

In other words, the fundamental assumption in this article is that the individualistic citizen is the logical result of societal developments in recent years, and that the position represents a subjectivization and individualization of the political, which may be tantamount to a weakening of the democratic community. On the basis of this assumption - that citizens increasingly pursue their own interests and legitimize their political choices or interests on the basis of a perception that this is the way they simply think that things should be done - then less consideration is granted to the common good and to political issues being regarded from more than one side. But of course, the question is whether this is indeed the case.

In the following, our inquiry will first focus on whether the individualistic citizen type is becoming increasingly widespread or whether it is a marginal and therefore rather uninteresting category.

Second, our investigation will focus on whether the individualistic citizen holds a different view on, e.g., politics and democratic norms than does the population at large. The assumption is that this group has a particular perspective on the political, such that 
their own interests are in focus. The consequence of this may be that one then also underestimates the ordinary democratic norms. If this is the case, then it is truly possible to point out long-term democratic problems. On the other hand, while one is able to observe a group of individualistic citizens, they may not distinguish themselves significantly from the rest of the population. There is, therefore, no reason to talk about dramatic democratic problems. We will primarily rely on quantitative data when examining this more closely.

Third, we will examine in more detail the manner in which this group articulates their own relationship to politics and the media in practice. Why has one group - despite their political involvement - not included the news coverage provided by the conventional media as a pivotal point in their everyday life? The hope here is that it will be possible to open the discussion to questions of relevance to political learning and political socialization. Qualitative data will predominantly be employed to this end.

\section{The Individualistic Citizen}

There is evidence indicating that observations regarding the presence of individualistic citizens in Danish society are not entirely awry. For example, Table 1 indicates the spread of the types referred to above. In practice, of course, actual media use may be quite different. Some rely on the newspaper, while others depend more on the television; some use all forms of media, while others only use a single media source.

The general typology in Table 1 is constructed on the basis of a comparison of three different forms of media consumption: the use of newspapers, radio and television. If one uses at least one of these media sources daily to acquire information about politics, one is tallied as an active media consumer. As there is considerable overlap between the different forms of media consumption, this coupling means that 50 per cent of the Danish population can be characterized as active media users, as they at least make use of the newspaper, radio or television - or all of the above - to obtain news about politics.

Table 1. Political Interest and General Media Consumption in Relation to Keeping up with Political Events, 2004 (per cent)

\begin{tabular}{llll} 
& \multicolumn{1}{c}{$\begin{array}{l}\text { Political interest } \\
\text { Widespread }\end{array}$} & Limited \\
\hline $\begin{array}{l}\text { Use of the } \\
\text { media for } \\
\begin{array}{l}\text { political } \\
\text { orientation }\end{array}\end{array}$ & $\begin{array}{l}\text { Daily } \\
\text { Occasionally }\end{array}$ & The active citizen $40 \%$ & The faithful citizen $10 \%$ \\
\hline
\end{tabular}

There are also different ways of calculating political interest. In this study, the people indicating that they are 'very' or 'somewhat' interested in politics are placed together, while those saying that they are only 'slightly' or 'not at all' interested in politics are placed together. The result is that 63 per cent claim an interest in politics, while 37 per cent only have a limited interest in politics.

These two calculations have been cross-referenced in Table 1, which demonstrates the general division into the four types. As expected, the 'active citizen' is the most widespread type, covering 40 per cent of the population. The 'indifferent citizen' in- 
cludes 27 per cent of the population, while 23 per cent of the population falls into the 'individualistic' category. Finally, only 10 per cent can be regarded as 'faithful citizens'.

Examining the social background of the four citizen types more closely, as accounted for in Table 2, it is hardly surprising that men, the so-called '68-generation', the postwar generation, seniors, and persons with secondary schooling are all over-represented among the active citizens. This is entirely in line with other studies of political activity.

Table 2. Citizen Types and Social Background, 2004 (per cent)

\begin{tabular}{|c|c|c|c|c|}
\hline & \multicolumn{4}{|c|}{ Citizens } \\
\hline & The active & The individualistic & The faithful & The indifferent \\
\hline \multicolumn{5}{|l|}{ Gender } \\
\hline Men & 46 & 25 & 8 & 21 \\
\hline Women & 35 & 21 & 12 & 33 \\
\hline \multicolumn{5}{|l|}{ Age - year of birth: } \\
\hline $1975-87$ & 25 & 28 & 10 & 27 \\
\hline $1960-74$ & 34 & 24 & 10 & 33 \\
\hline $1945-59$ & 45 & 24 & 7 & 24 \\
\hline $1930-44$ & 51 & 16 & 13 & 20 \\
\hline before 1930 & 49 & 19 & 17 & 16 \\
\hline \multicolumn{5}{|l|}{ Education } \\
\hline Elementary school & 36 & 23 & 13 & 28 \\
\hline $\begin{array}{l}\text { Secondary school, } \\
\text { e.i. high school }\end{array}$ & 45 & 22 & 6 & 26 \\
\hline Total & 40 & 23 & 10 & 27 \\
\hline
\end{tabular}

Table 2 also illustrates that men and youth are overrepresented among the individualistic citizens. This provides a sense that there may in fact be some truth to the notion that the individualistic citizen type can be perceived as a logical consequence of contemporary societal developments, which is supported by the fact that this type is manifested most clearly among young people.

As regards the faithful citizen, women, the post-war generation and persons with very limited education (no secondary education) are overrepresented. Finally, women and the 80 s-generation are overrepresented in the indifferent group. The latter might be somewhat surprising, but this is in fact in line with other studies indicating that young people are generally uninterested in politics. In other words, among the two youngest generations, one can observe a polarization of the political culture among young people, with the 'interested' on one side and the 'uninterested' on the other. What they have in common is that they do not keep up with the news on a daily basis.

It is not possible to make generalizations about developmental tendencies on the basis of a single study. Doing so requires data from several different points in time. Such an account is presented in Table 3, which indicates the combination of political interest and media consumption for a number of different media sources, as observed in 1990, 1998 and 2004. Again, there is reason to proceed with caution when making (too) firm conclusions about developmental tendencies. Thus, the development in political interest does not merely reflect a long-term tendency; it is also influenced by actual 
events, which for a brief period of time can spark extraordinary bursts of interest. This was the case in 1998, when both an exciting political situation surrounding an election to the Danish parliament, the Folketing, and dramatic events in the EU prompted interest to surge to unusually high levels. Since that time, it has settled down to the 'ordinary' level.

Table 3. Political Interest and Media Activity, 1990, 1998 and 2004 (per cent)

\begin{tabular}{|c|c|c|c|c|c|c|}
\hline \multirow{2}{*}{$\begin{array}{l}\text { Use the following } \\
\text { media to keep up } \\
\text { with political events: }\end{array}$} & \multicolumn{2}{|c|}{$\begin{array}{c}\text { Political interest } 1990 \\
\text { Not }\end{array}$} & \multicolumn{2}{|c|}{$\begin{array}{c}\text { Political interest } 1998 \\
\text { Not }\end{array}$} & \multicolumn{2}{|c|}{$\begin{array}{c}\text { Political interest } 2004 \\
\text { Not }\end{array}$} \\
\hline & Interested & interested & Interested & interested & Interested & interested \\
\hline \multicolumn{7}{|l|}{ Newspapers } \\
\hline Often/daily & 47 & 23 & 53 & 8 & 20 & 2 \\
\hline Occasionally or rarely & 14 & 15 & 19 & 20 & 42 & 35 \\
\hline \multicolumn{7}{|l|}{ Radio } \\
\hline Often/daily & & & 46 & 9 & 22 & 5 \\
\hline Occasionally or rarely & & & 26 & 19 & 41 & 33 \\
\hline \multicolumn{7}{|l|}{$T V$} \\
\hline Often/daily & & & 58 & 15 & 35 & 8 \\
\hline Occasionally or rarely & & & 14 & 13 & 28 & 29 \\
\hline \multicolumn{7}{|l|}{ Internet } \\
\hline Often/daily & & & - & - & 5 & 1 \\
\hline Occasionally or rarely & & & - & - & 58 & 37 \\
\hline Total & 61 & 38 & 72 & 28 & 63 & 38 \\
\hline
\end{tabular}

That said, it is especially possible to examine the development in the use of newspapers more closely. We have examined three different years in order to observe development, and the tendency is quite clear: There are an increasing number of politically interested people who do not use the newspaper on a daily basis to keep up with politics. In other words, on the basis of newspaper consumption alone, there would appear to be an increasing number of individualistic citizens. At the same time, the number of indifferent citizens is increasing, while the number of faithful citizens is falling drastically; yet another observation that is hardly surprising. Who wants to subscribe to a newspaper just on the basis of tradition when one can obtain the 'necessary' information by other means and no longer must subscribe to a specific newspaper because of party affiliation or the like?

When it comes to radio and television use, the study only includes two different years, of which one (1998) in particular unfolds in a situation that met with especially great political interest. Nevertheless, a picture demonstrating the same tendency begins to appear. There is an increasing number of individualistic citizens and more indifferent citizens, while there are fewer active citizens, as indicated both by radio and television use. Internet use is also included in this account, but here there are still so few daily users that it cannot be construed as an alternative to the other media. Internet use is therefore hardly interesting in this connection.

After getting this far, we thus assume that over the course of the past 15 years, there has been an increasing number of individualistic citizens in Denmark. These are citizens who are interested in politics, on the one hand, but who keep up with the news in the media to a limited extent, on the other. The question now is whether they represent a new 
group with a unique political culture, in which the subjective and individualistic aspects are at the forefront at the expense of democratic norms and a sense of the common good, or whether this group only distinguishes itself from the rest of the population as regards its media habits. This will be examined more closely in the following section.

\section{Individualism, Politics and Democratic Norms}

The data available for this study enable us to look more closely at the extent to which the individualistic citizens distinguish themselves from others in terms of levels of knowledge, political self-confidence and democratic norms. There is only talk of isolated snapshots, but hopefully these snapshots will provide a sense of what - possibly - is at play in relation to the political culture of the different groups.

The point of departure is the assumption that reflexive individualization is most apparent in terms of an emphasis on personal interests, subjectivization and an interest in personally making a difference in relation to the political sphere at the expense of the emphasis on democratic norms, orientation in relation to the community and the strengthening of the opportunities available to the people to exercise influence.

When it comes to the individual's assessment of his/her own insight and knowledge about politics, the active citizens score highest. This is apparent in Table 4. This may not be particularly surprising, as they are people who are both interested in politics and follow the news media on a daily basis. It is therefore quite natural that many of those exhibiting this type of behavior perceive themselves as people with a good understanding of politics; however, they are very closely followed by the individualistic citizens, whose level is almost as high as that of active citizens. And both are far above the levels of the faithful and the indifferent, the latter in particular. Unfortunately, the available data do not include questions about actual knowledge, rendering it impossible to test the assessments of the respondents in practice.

The active and individualistic persons also frequently discuss politics and pursue arguments and their own viewpoints in these discussions, yet again far above the level found among the faithful and the indifferent. However, one might have expected that especially conversations with others would be what provided better insight for the individualistic citizens - on the grounds that they do not make use of news media on a daily basis - but there is no evidence indicating that discussions play a particular role here. As already mentioned, they follow the active type relatively closely.

As regards self-confidence, it is hardly surprising that the active citizens exhibit the highest levels of political self-confidence. This is entirely in line with the most common assumptions regarding political socialization and learning, where political interest motivates the individual to become involved in activities that provide experiences that again contribute to the reinforcement of self-confidence (Goul Andersen 2000, Kaid (ed.) 2004, p. 357f). As shown in Table 4, 40 per cent of them would take the political initiative if they found there was reason for doing so. And they also have a certain measure of faith that the Danish parliament, the Folketing, and the government listen to them when they speak. The individualistic citizens do not have quite the same high level of political self-confidence. First and foremost, they have considerable doubts as to whether they would take the initiative if the Folketing were considering proposed legislation that was regarded as unjust or dangerous. This is something that can hardly be related to the individualist approach, as inquiry is directly leveled at both individual and collective initiatives. In any case, the confidence among individuals lies close to the 
Table 4. Assessment of Knowledge about Politics and Democracy in Denmark, Together with Political Self-confidence, 2004 (per cent)

Per cent that agree with the

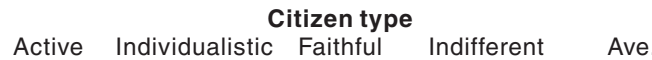

following statement:

Knowledge

I feel that I have a pretty good

understanding of the important political

issues in Denmark.

84

78

51

41

68

I believe other people in Denmark are

more informed about politics and

government activities than I am.

I often discuss politics when I am to-

gether with friends, family or colleagues. 89
When I have a strong opinion about a

political issue, I often try to convince my

friends, family or colleagues that they

ought to share my views.

70

15

30

34

19

80

42

36

68

Self-confidence

It is likely that - alone or together with

others - I would do something if the

Danish parliament, the Folketing, was

considering legislation that I felt was

unjust or detrimental.

40

17

20

If I were to do/organize something,

I believe that the Parliament would deal

with my views seriously.

People like me don't have any influence

on what the government does.

View on politics and democracy

in Denmark

Referenda are a good way of making political decisions.

Political parties encourage people to become active in politics.

$\begin{array}{lllll}75 & 77 & 81 & 78 & 77 \\ 43 & 34 & 30 & 26 & 35 \\ 31 & 33 & 32 & 23 & 29 \\ 38 & 28 & 26 & 25 & 31 \\ 32 & 32 & 17 & 23 & 28\end{array}$

Political parties do not provide voters with genuine choices.

Religious extremists must have the right to conduct public meetings.

Groups that are judgmental of other races or ethnic groups must have the right to conduct public meetings.

Assessment of the wellbeing of democracy (0: poor - 10: good):

Today

10 years ago

average, which must be seen in connection with the observation that self-confidence among the faithful and indifferent citizens is relatively low.

When considering tolerance towards religious extremists and racists, the individualistic citizens demonstrate a rather vacillating course. Their tolerance is lowest in relation to religious extremists, while it is greatest in relation to groups who are judgmental about other races and ethnic groups.

Finally, the individualistic citizens do not distinguish themselves significantly from others in relation to views on politics and democracy. They do not demonstrate a unique 
form of critique or cynicism in relation to the political parties, nor does their assessment of the value of referenda deviate from the other groups. One can possibly catch a glimpse of a measure of critique as regards the notion that the parties constitute the path to genuine political choices, but this tendency is not entirely clear. As regards assessment of the wellbeing of contemporary democracy, they are close to the average. So yet again, it is not possible to trace critique, cynicism or optimism.

In summary, one can assert that the individualistic citizens' own assessment of their own knowledge, self-confidence, political institutions and the wellbeing of democracy in general lies very close to the average in Denmark. And in those instances where significant exceptions can be seen, the level is close to the relatively high level observed among the active citizens. The individualistic citizens enjoy discussing politics and do not experience problems keeping up with politics. It is only in the case of tolerance that they demonstrate distinctly different behavior. The question now is whether they also score close to average in relation to the emphasis placed on democratic norms.

Table 5. Assessment of Democratic and Political Norms, 2004 (per cent)

\begin{tabular}{|c|c|c|c|c|c|}
\hline \multirow{2}{*}{$\begin{array}{l}\text { Assessment of the importance of the } \\
\text { following democratic norm } \\
\text { (0: not important - 100: very important): }\end{array}$} & \multicolumn{5}{|c|}{ Citizen type } \\
\hline & Active & Individualistic & Faithful & Indifferent & Ave. \\
\hline \multicolumn{6}{|l|}{ Democratic norms - respect for the law } \\
\hline Always following the rules and the law & 87.3 & 86.8 & 90.9 & 87.6 & 88.2 \\
\hline \multicolumn{6}{|l|}{ Political activities } \\
\hline Always voting in public elections & 95.4 & 93.6 & 89.9 & 85.8 & 91.2 \\
\hline $\begin{array}{l}\text { Always keeping an eye on what public } \\
\text { authorities are up to }\end{array}$ & 79.1 & 75.2 & 73.6 & 68.1 & 74.0 \\
\hline $\begin{array}{l}\text { Being active in social and political } \\
\text { associations }\end{array}$ & 54.2 & 51.4 & 42.4 & 39.9 & 47.0 \\
\hline $\begin{array}{l}\text { Choosing products on the basis of } \\
\text { political, ethical or environmental } \\
\text { grounds, even if it might cost a little more }\end{array}$ & 64.8 & 60.6 & 62.2 & 55.0 & 60.7 \\
\hline \multicolumn{6}{|l|}{ Tolerance } \\
\hline $\begin{array}{l}\text { Trying to understand the thinking of } \\
\text { people with other views }\end{array}$ & 85.0 & 81.8 & 76.2 & 74.4 & 79.4 \\
\hline \multicolumn{6}{|l|}{ Solidarity and welfare } \\
\hline $\begin{array}{l}\text { Helping people in Denmark who are } \\
\text { less well-off than oneself }\end{array}$ & 80.0 & 74.8 & 75.8 & 73.3 & 76.0 \\
\hline $\begin{array}{l}\text { Helping people in the rest of the world } \\
\text { who are less well-off than oneself }\end{array}$ & 71.3 & 67.1 & 65.5 & 63.1 & 66.8 \\
\hline $\begin{array}{l}\text { Ensuring that all citizens enjoy a } \\
\text { reasonable standard of living }\end{array}$ & 92.9 & 90.9 & 93.8 & 92.0 & 92.4 \\
\hline
\end{tabular}

As seen in Table 5, considerable importance is generally attributed to the fundamental democratic norms concerning respect for the law. Here, the individualistic citizens' assessments of themselves lie at the lowest level; however, the difference between the active and individualistic scores is not significant. Conversely, the faithful and the indifferent assessed the norms significantly higher than did the individualistic citizens. In other words, there is evidence indicating that political interest is synonymous with a general assessment of the importance of respect for the law that is slightly lower than among the rest of the population. Furthermore, one gets a sense that it is the individu- 
alistic citizens in particular who assume this position. Though as mentioned, this difference is not statistically significant, so one cannot draw extensive conclusions on the basis of these figures. This may be because individualistic citizens, based on their political interest, are willing and able to become involved and negotiate things and feel they do not always have to follow the letter of the law if better results can be achieved by bending the law according to prevailing conditions and available opportunities, i.e. a more reflexive approach to the law.

As regards assessment of the importance of various political activities, the individualistic citizens' own assessments are slightly above average. The active citizens place the greatest emphasis on political activities, whereas the indifferent citizens place the least emphasis on them, which is indicative of their general political interest. In relation to tolerance, the individualistic citizens are close to average and relatively distant from the active. This is hardly surprising when one compares this assessment with the aforementioned views about the rights of various groups to conduct public meetings.

Interestingly enough, however, it becomes apparent that the sense of solidarity displayed by the individualistic citizens towards those who are less fortunate - both in Denmark and globally - is at the bottom of the scale, near the indifferent citizens. Here, they distinguish themselves significantly from the assessment made by the active citizens as regards the importance of solidarity. The same is true of their assessment of the importance of ensuring a reasonable universal standard of living. In other words, universal welfare holds little appeal for individualistic citizens.

In summary, then, one can say that the active and individualistic citizens are in line with one another as regards their assessment of the fundamental democratic rules of play, with the individualistic citizens scoring at somewhat lower levels. Their paths divide, however, in relation to their respective assessments of tolerance, solidarity and welfare. Here, the individualistic citizens score significantly lower than the active citizens.

In summary, the image of the individualistic citizens can be sketched as a group with political self-confidence that is interested in debate - a group that evaluates their own level of knowledge as being relatively high. They do not distinguish themselves very much from the average in this regard. Nor do they do so in relation to their assessment of political activities; contexts in which the active citizens score at the highest level. Conversely, it is possible to point out interesting discrepancies as regards assessment of the fundamental democratic rules of play, where they attain the lowest scores. This is also the case when solidarity and welfare are on the agenda.

In relation to some questions, this group then lies close to the active citizens, while in relation to other questions the group is close to the faithful and indifferent citizens. They are relatively positive in relation to the political community. The most significant exception concerns respect for the law, but here they are close to the active citizens. Conversely, they score lowest as regards solidarity and welfare, i.e. questions regarding the social situation of the community. Moreover, there are also very shifting in their opinions about tolerance. These observations may indicate that, in central areas, these individuals either underestimate the significance of the common good or follow subjective views rather than fundamental common principles.

In summary, one can then see characteristics among the individualistic citizens that point in the direction of the subjectivization and reflexive individualization that has been raised as a hypothesis in the introduction. However, this is hardly a question of unambiguous tendencies. The question then becomes how representatives for the individu- 
alistic citizens articulate their own political universe. Some thoughts on this are presented below.

\section{Power and Media}

In the following, a number of examples of possible types of identity constructions will be given that are of relevance to the coupling of high political interest and limited media consumption, as they thematize the elements of politics that form meaning and opinion in this regard. The statements stem from a number of qualitative interviews (Kristensen 2003). In this connection, however, it must be specified that these empirical data are derieved from a different study with research questions somewhat different from the studies we have used as the basis for the individualistic citizen type thus far. The qualitative data stem from a study under the Danish Democracy and Power Study, which included attempts at mapping the perceptions of the power relations in Danish society held by the people of Denmark, as well as their sense of their own role in Danish democracy. In other words, the persons classified in this article as 'individualistic citizens' are not necessarily the same persons who formulate their views in the qualitative section.

As such, there are methodological problems affecting comparison of the different types of data with one another - and it is by no means possible to draw direct conclusions between the studies. Thus, the following only represents our interpretations of the possible relationships, which are first and foremost of an illustrative character. However, we find it defendable - as well as interesting - to dwell upon a number of possible and more explanatory variables, which can help indicate the tendencies that we have observed and described thus far. It is therefore somewhat thought-provoking that it appears to be possible to recognize the individualistic citizens in the existing qualitative data, some examples of which will be provided below.

Per Nielsen is 56 years old and receives a disability pension. He is divorced and lives alone in a townhouse. He has various small jobs, including a "skånejob", a job created and funded by the municipality whereby he works approximately fifteen hours a week in a small, local gymnastics club in Jutland. Per is definitely reflexive and politically interested, but he is not politically active. He points out that the television contributes to determining a number of specific perceptions of politicians, which are not particularly flattering.

Per: I think that there is a kind of devaluation of politicians that is going on. And I think that television contributes to it. It's getting to the point that all of their statements are reduced to headlines. They keep repeating everything until you've fallen asleep. They have those kinds of statements that they repeat on a semi-annual basis. In other words, it's almost only individual cases - you can't really get a grasp of extensive policy through the TV. It's impossible. You can hardly do so by reading the newspaper. But then the one side acts offended and furious, and the other side gets kind of defensive. You get tired of that, but apparently it's all you get.

Per is against the general presentation of politics and the political game in the media. He has an image of the game and has seen through the presentation, seeing it as being characterized by simplification, entertainment, theatrics and (partially artificial) dichotomies.

Finn Berg represents yet another example. He is 58 years old, lives in Copenhagen and drives a taxi. In the past, he has worked in the world of banks and finance and has 
been a state-authorized real estate agent, but has since dropped his career in order to live "the free as a bird" life of a taxi driver. Finn stresses that the media determine our way of thinking to a great degree, and he uses the Danish Prime Minister as an example of how the media and politics are coupled and utilized for dramatization, personification and manipulation.

Finn: Our Prime Minister in Denmark today - he's a media figure. You can just see how he has imitated Tony Blair, who suddenly started imitating Clinton. They're always promoting themselves. I mean, they know what kind of power they have. That's also why "de autonome" ${ }^{1}$ react. They're smart. That's why they react - to get at the hypocrisy. They throw an egg at his [the Danish Prime Minister's] head when he's out to donate DKK 22,000 to some kind of shelter (in Nørrebro), and at the same time he's sitting there and has power over all of the cutbacks that affect the down-and-out. And he has "sold" to the public the message that he has done something for these people. And the moment he's in the media, he gets an outpouring of sympathy from the entire population. They think that it's too damn much that the Prime Minister is hit in the head with an egg. But is it? Is it? I don't know. It has something to do with power. I won't justify it. I just want people to see it.

Finn explains that essentially everything that happens in society is politics, i.e. related to power. But power is something he distances himself from, not least when power assumes the character of 'hypocrisy'. Finn is very politically interested, but not active himself. "I think that others will regard me as an anarchist or provocateur. I don't want power over anyone, but there sure as hell better not be anyone who has power over me - that's what my need for freedom is all about," he explains. Finn is revolted by the "play for power." Conversely, he is obviously an individualistic person who celebrates personal autonomy.

Most of the respondents have apparently seen through much of the strategic communication, as well as the functions and roles of the media, including the ability to serve as a political 'spokesman' or democratic 'watchdog'. Read what Lisbeth Begtrup has to say, for example:

Lisbeth: I mean, if there is something that's causing you problems or something you can't get through the system - then you can go to the media. And then suddenly they're able to move mountains for you.

Susser Feit is 47 years old and resides north of Copenhagen. She has a master's degree in economics and business administration and works as a journalist and consultant. She has also seen through the game and the political mechanisms surrounding the media world, though this does not mean she regards the media as the means of power for certain actors:

Susser: (the political) agenda isn't steered by the media - it's steered by the people who are good at presenting what the media want. It's a misunderstanding to say that things are controlled by the media. The parties, the business community, trade unions and professional associations and whoever - they use the media. They know how the media works and that the readers want drama. That's the case for all of the actors in society who know how things are supposed to be presented in order for the media to take notice. The members of the media are just doing their jobs. They have to earn money, and they know what to do. BT [a 
Danish tabloid newspaper] is well aware of which headlines sell newspapers and the same is the case for the magazine publishers and TV-Avisen [the news transmission produced by the Danish public service television station].

The respondents referred to above represent a perspective on how the media present a political life that is in many ways somewhat cynical (and doubtlessly realistic), including the various 'behind the scenes' interests and power mechanisms. Moreover, a consistent observation is that the respondents have problems recognizing their personal political identity in the selections and 'angles' in the political coverage. At the same time, they object to the depictions presented to them. In the concluding section, we will examine the possible implications of this more closely as regards citizenship, political engagement and the public.

\section{Conclusion}

In this article, we have attempted to examine the consequences of changing media habits combined with the political interest as regards political socialization, learning, democratic citizenship and the political public. Beginning with the latter, the general perception is that the contemporary media play a rather decisive role in Danish democracy. One can therefore hardly conceive democratic regulation of a modern, complex society without the intervention of the mass media (Hjarvard 1995). In other words, according to this understanding, the media occupy an entirely central role in relation to the democratic processes, as they have gradually assumed important elements of the functions that were formerly taken care of by the political parties in Denmark. Owing to the extent of their organization, the parties formerly served as a guarantee for the communication of information and opinions to their members via meetings, internal publications, flyers, the party press, etc. In keeping with the classical Habermasian ideal of the public, parties constituted the means of communication as well as the very public. This function has gradually been taken away from the parties and instead - in the orthodox (theoretical) perception - it has been left to the media to communicate to the public.

According to the Habermasian ideal (Habermas 1981), public dialogue - and not least a critical public - serves to improve the basis of information, increases the level of reflection, and augments the sense of responsibility among decision-makers. Together with free choice and party competition, in short, more qualified decisions are made, as the decision-makers are forced to consider the overriding societal values and interests, which together constitute the foundation for the principle of popular sovereignty (Eriksen \& Weigård, 1999). That which precedes the actual election to public office the information level, dialogue and opinion formation - thus receives a fundamental status whereby the media can be attributed a decisive role in democracy. In order for the collective, public debate to unfold against the background of the best-informed foundation and according to optimal conditions, information about society, which serves as the basis for the knowledge and arguments used by citizens, must be present and optimal. Obviously, this places demands upon the channels of communication and sources that are to provide and deliver this information about society, i.e. the media.

The question then becomes, what happens to the democratic debate and political communication in a modern democracy if the connections are gradually cut between political elites and ordinary citizens? What happens to the formation of opinion? What happens to the political culture? And what consequences does this then have for political 
socialization, democratic learning or political participation? What happens to citizenship if the traditional citizen roles are gradually replaced by the emergence of the individualistic citizen?

Obviously, this article is not able to fully respond to all of these questions - but individual indications as to possible answers will be given. A particularly pressing question is thus, based on the findings presented, what can one imagine will happen to the political mobilization and learning processes? How are they to be created, developed and reproduced, if no longer via information from the media and debate in a shared public? The answer to these questions must to some extent be tied to central aspects of individualization and reflexivity, and thereby to the role of citizens in a democracy. More specifically, this concerns empowerment as a learning process, whereby political insight and political values are formed via concrete involvement, e.g. in the 'little politics'. One of the consistent characteristics of the individualistic citizen would appear to be a clear emphasis on individual autonomy. The larger political communities and collective mobilization do not appear attractive, among other reasons because it is felt to be far too difficult to reach agreement on a common, shared project. However, there is nothing wrong with their political interest, the consequence being that modern citizens empower themselves on their own, individually: one creates one's own spheres of opportunity and learns to develop them.

In this connection, it would be natural and tempting to tie our findings to Gidden's life politics concept. Life politics is exactly about the creation of self-identity, and thereby about individualization and reflexivity. If the individual then increasingly constitutes the basis for politics and policy, this correspondingly and naturally undermines the need to keep up to date with the developments in 'the big politics'. This will then help to explain the reduction in media consumption observed in the group we are referring to here; however, one must be cautious about drawing overly extensive conclusions in this regard.

We have argued that there is an increasing subjectivization of the political sphere in which the acquisition of political values, as a result of the above, is increasingly occurring independent of the mass media. We are by no means writing off the value of traditional channels for political socialization and learning, but the point is that political interest is separate from media consumption. At the same time, Table 4 indicates that these channels do not merely appear to have been replaced by other well-known channels, including debate with family and friends. These relationships then leave us with a pressing question, i.e. how do socialization and learning proceed if the political public is increasingly experienced as having evaporated, and insofar as the media do not act in relation to the ideals and conceptions of the public?

On the basis of both the quantitative and qualitative data, there is much to indicate that many people no longer experience the existence of a public in the classical sense. Many people, thus, reject the mass media as their source of knowledge and political values. In this connection, Table 3 demonstrates a particularly massive and remarkable fall over time in media consumption among the politically interested. This must inevitably be thought to have clear consequences for democratic citizenship - for the democratic conversation - and the common interests concurrently with the fall in the opinion-forming impact of the media. This then thematizes the question of how the citizens alternatively convert political information and argumentation to political opinions, and to some extent the question of how we must then state the reasons for the observed development. 
In this connection, a possible explanation could be a general rejection of that which Jørn Loftager refers to in his publication as part of the Danish Democracy and Power Study (Loftager 2004) as the "play for power," which is in perfect harmony with the statements presented in this article. When the mass media focus more on political power showdowns than on substantial political programs and questions as to what the politicians represent, democratic problems develop, as the voters lack the issue-oriented information upon which they are to form their opinions.

Next, it can be claimed that the political sphere has grown and spread significantly over the course of recent decades, cf. the "explosion of politics," as it has been referred to in Denmark (Pedersen et al. 1994). The time when journalists could narrowly focus on the national parliamentary and national economic conditions is long gone. Contemporary politics are much more about the opportunities available to the individual to realize himself/herself, as well as the organic, cultural and identity-based questions (Giddens 1996, Beck 1992, Gibbins \& Reimar 1999). These questions did not receive the same weight and significance in the past. At the same time, this places demands on the media, which are expected to provide an information service that appeals to the total life situation of the recipients, including public as well as private roles (Hjarvard 1999). An actual 'match' between one's own life situation and the depictions of politics and democracy is hardly possible any longer in a modern, functionally differentiated and 'culturalized' society. But if the gap between these poles is felt to be too large, then this can quite conceivably undermine the general interest in the media, while at the same time political engagement remains intact.

For it would appear as though many people are encountering problems in rediscovering their own political identity in the image constructed by the media, and at the same time, it has become more difficult to catch a glimpse of a classical political public. The consequence of a separation of political interest from the consumption of news coverage in the media can therefore contribute to further erosion of the political public. In addition to the argument made here about the subjectivization of politics, there is indeed ample evidence indicating a widespread experience of politics as primarily consisting of theatrics, the cult of personality, and political commercialization. The individualistic citizen has seen through these mechanisms and simply says, "I don't feel like it."

\section{Note}

1. Left-wing political extremists, predominantly young people.

\section{Quantitative data}

The quantitative study is primarily based on data from a representative investigation of democracy and citizenship, conducted by the Department of Economics, Politics and Public Administration, Aalborg University, within the framework of the ISSP (the International Social Survey Program). Data collection was carried out by the Danish National Institute of Social Research (Socialforskningsinstituttet) in 2004, and a total of 1167 respondents participated.

Data from an election study in 1990 and a research project entitled Democracy from Below (1998) have been used to construct Table 3. 


\section{References}

Andersen, J. (1993) Medborgerskab. Demokrati og politisk deltagelse. Herning: Systime.

Bang, H. (ed.) (2000) Demokrati fra neden. Casestudier fra en dansk kommune. Copenhagen: Jurist- og Økonomforbundets Forlag.

Beck, U. (1992) Risk Society: Towards a new Modernity. London: Sage.

Buckingham, D. (2000) The Making of Citizens. Young People, News and Politics. London: Routledge.

Gibbins, J.R. \& Reimer, B. (1999) The Politics of Postmodernity. An Introduction to Contemporary Politics and Culture. London: Sage.

Giddens, A. (1996) Modernitet og selvidentitet. Selvet og samfundet under senmoderniteten. Copenhagen: Hans Reitzels Forlag.

Goul Andersen, J. et al. (1999) Den demokratiske udfordring. Copenhagen: Hans Reitzels Forlag.

Goul Andersen, J. (2000) Hvad folket magter. Demokrati, magt og afmagt. Copenhagen: Jurist- og Økonomforbundets forlag.

Habermas, J. (1981) The Theory of Communicative Action. London.

Hjarvard, S. (1999) Politik som mediemontage. Om mediernes forandring af den politiske kommunikation. In J. Goul Andersen et al.

Kaid, L.L. (ed.) (2004) Handbook of Political Communication Research. London: Lawerence Erlbaum Associates.

Loftager, J. (2004) Politisk offentlighed og demokrati i Danmark. Magtudredningen, Århus Universitetsforlag.

Nørgård Kristensen, N. (1998) Skolebestyrelser og demokratisk deltagelse. Stфvets Fortalling. Copenhagen: Jurist- og Økonomforbundets Forlag.

Nørgård Kristensen, N. (2003) Billeder af magten - portratter til forståelse af magt og demokrati. Magtudredningen, Århus Universitetsforlag.

Putnam, R.D. (2000) Bowling Alone. The Collapse and Revival of American Community. New York: Simon $\&$ Schuster.

Togeby, L. (2003) Magt og demokrati i Danmark. Hovedresultater fra magtudredningen. Århus: Århus Universitetsforlag. 